\title{
PERUBAHAN KARAKTERISTIK TANAH DAN PENAMPILAN BEBERAPA VARIETAS PADI GOGO PADA KAWASAN PESISIR DENGAN PENAMBAHAN PUPUK HAYATI DAN BIOKOMPOS
}

\author{
Yudhi Harini Bertham ${ }^{1}$, Abimanyu Dipo Nusantara ${ }^{1^{*}}$, Bambang Gonggo Murcitro ${ }^{1}$, \\ Zainal Arifin ${ }^{1}$
}

\author{
${ }^{1}$ Program Studi Ilmu Tanah, Fakultas Pertanian Universitas Bengkulu \\ * Corresponding Author: abimanyu.dn@gmail.com
}

\begin{abstract}
[CHANGE IN SOIL CHARATERISTICS AND PERFORMANCE OF UPLAND RICE VARIETIES IN COASTAL AREA AS AMENDED WITH BIOFERTILIZER AND BIOCOMPOST]. Dryland in the coastal area has good potential for the cultivation of upland rice to reach food self-sufficiency and the development of future agriculture. Low fertility of the land the area can be overcome by using appropriate technology such as the use of superior varieties,-bio-fertilizers, and bio compost. This study aimeds to (1) determine chemical and biological properties of coastal land to improve the growth of upland rice (2) find out the growth of upland rice in the coastal area using low input technology and (3) obtain upland rice varieties with high adaptability to a coastal area environment. The experimental-design used was a split-plot design with the main plot of 3 upland rice varieties, namely Inpago 10, Serantan, and Local Variety, while the subplots are were fertilizer inputs namely [double inoculant P solubilized microbial p (pf) $+\mathrm{K}$ solubilized microbially $+\mathrm{N}$ fixation microbial $\mathrm{N}$ ], [double inoculant $\mathrm{P}$ solubilized microbial (fma) $+\mathrm{K}$ solubilized microbially $+\mathrm{N}$ fixation micarobia], [biocompost at a dose of 10 tons/ha], and [inorganic fertilizer recommended by BPTP ie $200 \mathrm{~kg}$ Urea/ha, $100 \mathrm{~kg} \mathrm{SP} 36 / \mathrm{ha}, 100 \mathrm{~kg} \mathrm{KCl} / \mathrm{ha}$ ]. The results showed that the coastal area has the potential for the development of upland rice cultivation. Also, the double inoculants of biological fertilizers were able to increase plant nutrient uptake, soil biological characteristics, and the growth of upland rice as compared to controls. Specifically, the best treatment is produced by application of [double inoculant microbial solvent $\mathrm{p}(\mathrm{pf})+$ microbial solvent $\mathrm{K}+$ microbial $\mathrm{N}$ fixation] combined with upland rice Inpago variety 10 .
\end{abstract}

Keyword: coastal land, gogo rice, biofertilizer

\begin{abstract}
ABSTRAK
Pemanfaatan lahan kering pada kawasan pesisir untuk budidaya tanaman padi gogo mempunyai potensi besar untuk pemantapan swasembada pangan maupun untuk pembangunan pertanian ke depan. Keterbatasan kesuburan lahan di kawasan pesisir dapat diatasi dengan menggunakan teknologi yang tepat seperti penggunaan varietas yang unggul dan pupuk hayati serta biokompos. Penelitian ini bertujuan untuk (1) menjelaskan kmengetahui kemampuan kawasan pesisir berdasarkan sifat kimia, dan biologi dalam meningkatkan pertumbuhan padi gogo, (2) membuktikan daya tumbuh padi gogo di kawasan pesisir dengan teknologi masukan rendah, dan (3) mendapatkan varietas pagi gogo yang memiliki tingkat adaptasi tinggi di kawasan pesisir. Penelitian menggunakan rancangan petak terbagi (Split plot design) dengan petak utama adalah 3 varietas padi gogo berasal dari BPTP Bengkulu yaitu varietas Inpago 10, varietas Serantan, dan varietas Lokal Bengkulu, sedangkan anak petaknya adalah input pupuk yaitu [inokulan ganda mikroba pelarut $\mathrm{p}(\mathrm{pf})+$ mikroba pelarut $\mathrm{K}+$ mikroba pemfiksasi $\mathrm{N}$ ], [inokulan ganda mikroba pelarut $\mathrm{p}($ fma) + mikroba pelarut $\mathrm{K}+$ mikroba pemfiksasi $\mathrm{N}$ ], [biokompos dengan dosis 10 ton/ha], dan [pupuk anorganik rekomendasi BPTP yaitu $200 \mathrm{~kg}$ Urea/ha, $100 \mathrm{~kg} \mathrm{SP36/ha,} 100 \mathrm{~kg} \mathrm{KCl} / \mathrm{ha}$ ]. Kedua faktor tersebut dikombinasikan sehingga terdapat 12 kombinasi perlakuan yang diulang 4 kali sehingga terdapat 48 satuan percobaan. Hasil penelitian menunjukkan bahwa kawasan pesisir memiliki potensi untuk pengembangan budidaya padi gogo. Secara umum hasil penelitian menunjukkan bahwa inokulan ganda pupuk hayati yang digunakan mampu meningkatkan serapan hara tanaman, karakteristik biologi tanah dan pertumbuhan pagi gogo dibandingkan dengan kontrol. Secara spesifik perlakuan terbaik dihasilkan oleh aplikasi P1 [inokulan ganda mikroba pelarut p (pf) + mikroba pelarut K + mikroba pemfiksasi N] yang dikombinasikan dengan padi gogo varietas Inpago 10.
\end{abstract}

Kata kunci: lahan pesisir, padi gogo, pupuk hayati 


\section{PENDAHULUAN}

Indonesia memiliki panjang pantai terpanjang kedua setelah Kanada $81.000 \mathrm{~km}$ dengan luas laut 5,8 juta $\mathrm{km}^{2}$ (Budiharsono, 2001). Kadar garam yang tinggi pada lahan pesisir menyebabkan tekanan osmotik meningkat sehingga tanaman mengalami cekaman kekeringan. Di samping itu toksinitas ion seperti ionion $\mathrm{Cl}^{-}$dan $\mathrm{Na}^{+}$yang berlebihan, dan ketidak seimbangan unsur hara akibat penghambatan penyerapan nutrisi, serta kombinasi dari faktor-faktor tersebut (Ashraf \& Harris, 2004; Gorham, 2007). Pemanfaatan lahan pesisir khususnya di Provinsi Bengkulu masih sangat terbatas, karena keterbatasan teknologi dan varietas untuk mengatasi masalah tersebut (Nurmegawati \& Wibawa, 2012). Sejauh ini, beberapa peneliti telah berhasil membudidayakan tanaman pada lahan pesisir yang terdapat di Bengkulu di antaranya yaitu cabai organik (Bertham et al., 2013), Gembili (Heriso et al., 2015), Kacang tTanah (Bertham \& Nusantara, 2017), Kedelai (Bertham et al., 2016, 2017, dan 2018), edamame (Nusantara et al., 2018), dan tTalas (Simamora et al., 2018).

Hasil beberapa penelitian membuktikan bahwa sebenarnya lahan pesisir mampu dijadikan sebagai lahan budidaya jika menggunakan teknologi yang tepat. Salah satu teknologi yang dapat diterapkan untuk memperbaiki sifat tanah pesisir adalah dengan memanfaatkan mikroba tanah yang ada di kawasan pesisir (in situ) seperti fungi mikoriza arbuskula, bakteri pelarut phospat, mikroba pelarut $\mathrm{K}$ dan azotobakter. Pemanfaatan mikroorganisme merupakan metode yang aman dan efektif untuk digunakan pada tanah pasiran. Tanah pasiran umumnya bersifat sangat porous sehingga penggunaan pupuk kimia akan sangat mudah tercuci dan hilang dari zone perakaran. Pemberian pupuk kimia pada tanah-tanah pasiran umumnya tidak efektif dan mudah hilang melalui perkolasi dan pelindian unsur haranya. Penggunaan mikroorganisme tanah pada tanah berpasir diyakini dapat meningkatkan ketersediaan unsur hara, air dan memperbaiki sifat-sifat fisik tanah. Menurut Sudaryono (2001) keberadaan mikroba di dalam tanah memegang peranan penting dalam transformasi yang menyebabkan perubahan sifat fisik dan kimia tanah.

Fungi mikoriza arbuskula merupakan tipe endomikoriza yang menyediakan unsur $\mathrm{P}$ bagi tanaman dari bentuk tidak tersedia dikarenakan peran dari enzim fosfatase (Oktaviani et al., 2014). Menurut Zuhry \& Puspita (2008), FMA dapat meningkatkan kemampuan akar dalam menyerap hara dan air untuk menunjang pertumbuhan dan perkembagan tanaman. Fungsi utama hifa adalah untuk menyerap air dari dalam tanah, $\mathrm{P}$ yang terakumulasi pada hifa eksternal akan segera diubah menjadi senyawa polifosfat dengan adanya enzim fosfatase (Nurhayati, 2012). Selain itu hasil penelitian Bertham (2002) menunjukkan bahwa mikoriza mampu melepaskan asam-asam organik sehingga terjadi peningkatan $\mathrm{pH}$.
Bakteri pelarut fosfat (BPF) merupakan salah satu mikroorganisme tanah yang mampu melarutkan ion $\mathrm{P}$ yang terikat $\mathrm{Al}, \mathrm{Fe}, \mathrm{Ca}$, dan $\mathrm{Mg}$ menjadi bentuk tersedia untuk diserap tanaman (Keneni et al., 2010). Bakteri pelarut fosfat mampu mensekresikan enzim fosfatase yang berperan dalam proses hidrolisis $\mathrm{P}$ organik menjadi $\mathrm{P}$ anorganik dan juga bakteri pelarut fosfat dapat menghasilkan zat pengatur tumbuh (Purwaningsih, 2003). Hasil penelitian Astuti et al. (2013) menunjukkan bahwa bakteri pelarut fosfat (BPF) mampu meningkatkan bobot basah, tinggi, kadar nitrogen $(\mathrm{N})$ dan kadar fosfor (P) tanaman tomat pada tanah masam.

Mikroba pelarut kalium dapat melarutkan kalium dari ikatan kalium tak larut pada suatu media melalui sekresi asam-asam organik dan mikroba pelarut kalium dapat memanfaatkan kalium terlarut pada suatu media untuk pembentukan sel-sel baru, sehingga terjadi pengikatan (immobilisasi) kalium oleh mikroba (Basak \& Biswas, 2009). Beberapa kelompok bakteri pelarut $\mathrm{K}$ diketahui mampu melarutkan K seperti Pseudomonas, Burkholderia, Azotobacter, Rhizobium, Bacillus, dan Paenibacillus (Hu et al., 2006; Singh et al., 2010 ; Don \& Diep, 2014).

Azotobacter adalah spesies rizobakteri yang telah dikenal sebagai agen biologis penambat $\mathrm{N}_{2}$ diazotrof, yang menkonversi dinitrogen ke amonium melalui reduksi elektron dan protonasi gas dinitrogen. Azotobacter vinelandii adalah bakteri gram-negatif yang mengikat nitrogen menggunakan nitrogenase holoenzyme yang memiliki kofaktor klaster molibdenum besi sulfat (FeMoCo) sebagai lokasi aktif (Chiu et al., 2001). Azotobacter hidup bebas sebagai saprofit di tanah, air tawar, lingkungan laut dan habitat alam lainnya dan telah digunakan sebagai inokulum efektif untuk meningkatkan pertumbuhan tanaman dan pengendalian hama (Aquilanti et al., 2004).

Padi gogo merupakan salah satu tanaman pangan yang berpotensi dikembangkan pada lahan kering di kawasan pesisir. Produksi padi 2016 sebesar 79.355.000 ton dengan luas panen 15.755.000 ha (produktivitas 5,236 ton/ha), yang terbagi atas produksi padi sawah sebesar 75.483.000 ton dengan luas area 14.633 .000 ha (produktivitas 5,397 ton/ha) dan produksi padi darat sebesar 3.872.000 ton dengan luas area 1.171.000 ha (produktivitas 3,307 ton/ha). Produksi padi 2017 sebesar 81.382.000 ton dengan luas panen 17.788.000 ha (produktivitas 5,155 ton/ha), yang terbagi atas produksi padi sawah sebesar 77.603.000 ton dengan luas area 14.633.000 ha (produktivitas 5,303 ton/ha) dan produksi padi darat sebesar 3.779 .000 ton dengan luas area 1.156.000 ha (produktivitas 3,270 ton/ha) (Kementerian Pertanian Republik Indonesia, 2017). Berdasarkan data tersebut maka terdapat penurunan produksi padi darat pada tahun 2017 yaitu sebesar 24.000 ton, yang disebabkan oleh penurunan luas area panen sebesar 13.100 ha serta penurunan produktivitas sebesar 0,112 ton/ha. 
Pemanfaatan lahan kering pada kawasan pesisir untuk budidaya tanaman padi gogo mempunyai potensi besar untuk pemantapan swasembada pangan maupun untuk pembangunan pertanian ke depan. Menurut Abdurachman et al. (2008) kebutuhan pangan selama ini ditunjang oleh padi sawah, yang dalam produksinya membutuhkan karakteristik lahan dengan tingkat kesuburan cukup tinggi. Karakteristik budidaya padi sawah yang demikian membatasi peluang peningkatan produksi beras melalui perluasan areal sawah. Hal ini karena sempitnya lahan cadangan yang sesuai untuk dijadikan sawah dan makin ketatnya persaingan penggunaan air dengan industri, pertambangan, dan rumah tangga.

Berdasarkan latar belakang di atas maka penelitian ini bertujuan untuk (1) menjelaskan kemampuan kawasan pesisir berdasarkan sifat kimia, dan biologi dalam meningkatkan pertumbuhan padi gogo, (2) membuktikan daya tumbuh padi gogo di kawasan pesisir dengan teknologi masukan rendah, dan (3) mendapatkan varietas pagi gogo yang memiliki tingkat adaptasi tinggi di kawasan pesisir.

\section{METODE PENELITIAN}

Penelitian dilaksanakan pada bulan Juli 2019 sampai dengan Februari 2020 di Kelurahan Beringin Raya Kecamatan Muara Bangkahulu kota Bengkulu. Pembuatan inokulan pupuk hayati dilakukan di laboratorium Biologi Tanah, Fakultas Pertanian Universitas Bengkulu. Sedangkan pengukuran bobot kering tanaman, analisis tanah awal dan akhir, serta kadar hara jaringan dilakukan di LaboratoriumIlmu Tanah,Fakultas Pertanian, Universitas Bengkulu.

Rancangan percobaan yang digunakan adalah rancangan petak terbagi (Split plot design) dengan petak utama adalah 3 varietas padi gogo yang didapatkan dari BPTP Bengkulu yaitu varietas Inpago $10\left(\mathrm{~V}_{1}\right)$, varietas Serantan $\left(\mathrm{V}_{2}\right)$, dan varietas Lokal Bengkulu $\left(\mathrm{V}_{3}\right)$. Anak petaknya adalah input pupuk yaitu $\mathrm{P}_{1}$ [inokulan ganda mikroba pelarut $\mathrm{p}$ (pf) + mikroba pelarut $\mathrm{K}+$ mikroba pemfiksasi $\mathrm{N}$ ], $\mathrm{P}_{2}$ [inokulan ganda mikroba pelarut $\mathrm{p}(\mathrm{fma})+$ mikroba pelarut $\mathrm{K}+$ mikroba pemfiksasi $\mathrm{N}], \mathrm{P}_{3}$ [biokompos dengan dosis 10 ton/ha], dan $\mathrm{P}_{4}$ [pupuk anorganik rekomendasi BPTP yaitu $200 \mathrm{~kg}$ Urea/ha, $100 \mathrm{~kg} \mathrm{SP36} / \mathrm{ha}, 100 \mathrm{~kg} \mathrm{KCl} / \mathrm{ha}$. Kedua faktor tersebut dikombinasikan sehingga terdapat 12 kombinasi perlakuan yang diulang 4 kali sehingga terdapat 48 satuan percobaan. Setiap unit percobaan terdiri atas 50 tanaman sehingga jumlah total populasi tanaman adalah $50 \times 48=2.400$ tanaman. Data yang diperoleh dianalisis menggunakan analisis varian (ANAVA) taraf $5 \%$. Variabel yang berbeda nyata dianalisis lanjut dengan DMRT taraf 5\%.

\section{HASIL DAN PEMBAHASAN}

Hasil uji laboratorium menunjukkan bahwa tanah pada lahan penelitian mengandung $0,19 \% \mathrm{~N}$ yang tergolong rendah, $0,23 \% \mathrm{C}$-organik tergolong sedang, $0,28 \mathrm{me} / 100 \mathrm{~g}$ tanah $\mathrm{K}_{2} \mathrm{O}$ tergolong rendah, $6,23 \mathrm{ppm} \mathrm{P}_{2} \mathrm{O}_{5}$ tergolong rendah, dengan nilai $\mathrm{pH}$ $\mathrm{H}_{2} \mathrm{O}$ sebesar 6,2 yang tergolong agak masam, $\mathrm{pH}$ $\mathrm{KCl} 5,8$ yang tergolong agak masam, KTK sebesar $5,21 \mathrm{me} / 100 \mathrm{~g}$ tanah tergolong rendah. Berdasarkan data tersebut maka dapat disimpulkan tanah yang berada pada lokasi penelitian tergolong marginal dengan permasalahan kadar unsur hara, bahan organik, dan KTK tergolong rendah, serta $\mathrm{pH}$ agak masam.

Perbaikan tanah dilakukan lebih pada menyeimbangkan kembali hubungan simbiosis mutualisme atau hubungan yang saling menguntungkan pada alam. Mikroorganisme tanah seperti azotobakter, FMA, $\mathrm{BPF}$, dan BPK memiliki hubungan simbiosis mutualisme dengan tanaman berupa perbaiki kualitas kesuburan tanah. Dengan terjaganya kesuburan tanah maka daya ikat tanah terhadap air, terhadap unsur hara dan tanah sebagaisumber hidup utama tanaman akan terpenuhi. Hasil analisis varian menunjukkan bahwa perlakuan memberikan pengaruh nyata terhadap populasi Azotobakter dan populasi bakteri pelarut $\mathrm{K}$, namun memberikan pengaruh tidak nyata terhadap populasi FMA dan BPF.

Aplikasi $\mathrm{P}_{1}$ [inokulan ganda mikroba pelarut $\mathrm{p}$ (pf) + mikroba pelarut $\mathrm{K}+$ mikroba pemfiksasi $\mathrm{N}$ ] yang dikombinasikan dengan padi gogo varietas Inpago 10 menghasilkan populasi Azotobakter dan bakteri pelarut $\mathrm{K}$ lebih tinggi dibandingkan dengan perlakuan lainnya yaitu secara berturut-turut $25,87 \mathrm{koloni} / \mathrm{g}$ dan 120,03 koloni/g (Tabel 1). Hal ini mengindikasikan bahwa inokulan ganda pupuk hayati yang terdiri atas mikroba pelarut $\mathrm{p}(\mathrm{pf})+$ mikroba pelarut $\mathrm{K}+$ mikroba pemfiksasi $\mathrm{N}$ lebih cocok dengan rhizosfer varietas Inpago 10. Kualitas rizodeposisi (faktor yang mendorong kehadiran mikroba ke rizosfer) bergantung pada jenis tumbuhan (Jones et al., 2004; Bais et al., 2006). Rizodeposisi ini mengandung sel dan eksudat, gula, asam organik dan asam amino (Bertin et al,. 2003) yang digunakan mikroba sebagai substrat sehingga populasi meningkat (Doornbos et al., 2012).

Hasil penelitian menunjukkan bahwa populasi mikroorganisme tanah yang diamati pada rhizosfer tanaman yang diionulasi cenderung lebih tinggi dibandingkan dengan tanpa diinokulasi. Hal ini menun -jukkan bahwa pada dasarnya lokasi penelitian yang digunakan memiliki karakteristik sifat biologi tanah yang kurang baik sehingga populasi mikroorganisme cenderung rendah. Oleh karena itu, dibutuhkan inokulasi untuk meningkatkan keragaman dan kuantitas mikroorganisme tanah. 
Keberadaan mikroba dalam tanah berhubungan erat dengan kadar hara jaringan tanaman. Semakin tinggi populasi mikroba tanah maka kadar hara jaringan semakin meningkat. Kadar hara dalam jaringan tanaman menunjukan kadar hara aktual yang diserap oleh tanaman. Semakin tinggi kadar hara tanaman mengindikasikan semakin tinggi ketersediaan unsur hara hara dalam tanah yang mampu terserap oleh tanaman.

Tabel 1. Pengaruh perlakuan terhadap beberapa karakteristik biologi tanah

\begin{tabular}{|c|c|c|c|c|}
\hline Perlakuan & $\begin{array}{c}\text { Populasi } \\
\text { Azotobakter }\end{array}$ & $\begin{array}{c}\text { Populasi } \\
\text { FMA }\end{array}$ & $\begin{array}{c}\text { Populasi } \\
\text { BPF }\end{array}$ & $\begin{array}{c}\text { Populasi } \\
\text { BPK }\end{array}$ \\
\hline \multicolumn{5}{|c|}{ (koloni/g) } \\
\hline $\mathrm{V}_{1} \mathrm{P}_{1}$ & $25,87 \mathrm{a}$ & 121,79 & 150,38 & $120,03 \mathrm{a}$ \\
\hline $\mathrm{V}_{1} \mathrm{P}_{2}$ & $11,33 \mathrm{~b}$ & 169,23 & 166,03 & $119,87 \mathrm{a}$ \\
\hline $\mathrm{V}_{1} \mathrm{P}_{3}$ & $3,21 \mathrm{c}$ & 127,44 & 122,95 & $15,77 \mathrm{c}$ \\
\hline $\mathrm{V}_{1} \mathrm{P}_{4}$ & $2,56 \mathrm{c}$ & 124,36 & 136,28 & $11,28 \mathrm{c}$ \\
\hline $\mathrm{V}_{2} \mathrm{P}_{1}$ & $18,33 \mathrm{a}$ & 138,85 & 136,92 & $62,18 \mathrm{~b}$ \\
\hline $\mathrm{V}_{2} \mathrm{P}_{2}$ & $15,97 \mathrm{~b}$ & 155,13 & 127,56 & $55,77 \mathrm{c}$ \\
\hline $\mathrm{V}_{2} \mathrm{P}_{3}$ & $4,78 \mathrm{c}$ & 135,9 & 150,64 & $25,77 \mathrm{c}$ \\
\hline $\mathrm{V}_{2} \mathrm{P}_{4}$ & $1,92 \mathrm{c}$ & 127,56 & 133,46 & $13,85 \mathrm{c}$ \\
\hline $\mathrm{V}_{3} \mathrm{P}_{1}$ & $20,44 \mathrm{a}$ & 146,79 & 126,28 & $118,33 \mathrm{a}$ \\
\hline $\mathrm{V}_{3} \mathrm{P}_{2}$ & $16,03 \mathrm{a}$ & 162,18 & 152,82 & $106,54 \mathrm{a}$ \\
\hline $\mathrm{V}_{3} \mathrm{P}_{3}$ & $4,21 \mathrm{c}$ & 166,92 & 128,72 & $23,85 \mathrm{c}$ \\
\hline $\mathrm{V}_{3} \mathrm{P}_{4}$ & $3,85 \mathrm{c}$ & 140,51 & 133,97 & $24,49 \mathrm{c}$ \\
\hline Anava & \multicolumn{3}{|c|}{ ns } \\
\hline Kombinasi & $*$ & ns & $*$ \\
\hline Varietas & ns & ns & ns & ns \\
\hline Pupuk & $*$ & ns & $*$ & $*$ \\
\hline Ket : angka-angka yang diikuti oleh huruf yang sama \\
\hline pada kolom yang sama berbeda tidak nyata pada DMRT \\
$5 \%$
\end{tabular}

Menurut Stebbins \& Wilder (2003) konsentrasi hara daun dapat digunakan sebagai petunjuk untuk menentukan status hara tanaman yang polanya berhubungan langsung dengan pertumbuhan dan produksi tanaman. Hasil analisis varian menunjukkan bahwa perlakuan memberikan pengaruh terhadap $\mathrm{N}$ dan $\mathrm{K}$, namun berpengaruh tidak nyata terhadap nyata kadar hara $\mathrm{P}$, nilai $\mathrm{pH} \mathrm{KCl}, \mathrm{pH} \mathrm{H}_{2} \mathrm{O}$, dan kadar $\mathrm{C}$-organik tanah.

Aplikasi $\mathrm{P}_{1}$ [inokulan ganda mikroba pelarut $\mathrm{p}$ (pf) + mikroba pelarut $\mathrm{K}+$ mikroba pemfiksasi $\mathrm{N}$ ] yang dikombinasikan dengan padi gogo varietas Inpago 10 menghasilkan kadar $\mathrm{N}$, dan $\mathrm{K}$ tertinggi secara berturut-turut $0,57 \%$, dan $1,1 \%$. Hal ini berkaitan erat dengan populasi mikroorganisme yang mampu membantu tanaman dalam menyerap $\mathrm{N}$, dan $\mathrm{K}$. Pada Tabel 1 terlihat bahwa aplikasi $\mathrm{P}_{1}$ [inokulan ganda mikroba pelarut $\mathrm{p}(\mathrm{pf})+$ mikroba pelarut $\mathrm{K}+$ mikroba pemfiksasi $\mathrm{N}$ ] yang dikombinasikan dengan padi gogo varietas Inpago 10 menghasilkan populasi
Azotobakter dan bakteri pelarut $\mathrm{K}$ lebih tinggi dari perlakuan lainnya. Menurut Hindersah \& Simarmata (2004) ; Syam'un et al. (2012) bahwa Azotobacter $s p$. adalah salah satu spesies rizobakteri pemfiksasi dinitrogen yang mengubah dinitrogen menjadi amonium melalui reduksi elektron dan protonasi gas dinitrogen. Di sisi lain menurut Basak \& Biswas (2009) bahwa penggunaan BPK meningkatkan biomassa hasil dan penyerapan kalium. Oleh karena itu semakin tinggi populasi Azotobakter dan bakteri pelarut $\mathrm{K}$ maka semakin tinggi tanaman menyerap unsur $\mathrm{N}$, dan $\mathrm{K}$

Secara umum hasil penelitian menunjukkan bahwa inokulan pupuk hayati yang digunakan mampu meningkatkan serapan hara tanaman dibandingkan dengan kontrol. Hal ini terlihat dari Tabel 2 yang menunjukkan bahwa kadar $\mathrm{N}$ dan $\mathrm{K}$ jaringan tanaman pada $\mathrm{P}_{1}$ [inokulan ganda mikroba pelarut $\mathrm{p}(\mathrm{pf})+$ mikroba pelarut $\mathrm{K}+$ mikroba pemfiksasi $\mathrm{N}$ ], $\mathrm{P}_{2}$ [inokulan ganda mikroba pelarut $\mathrm{p}(\mathrm{fma})+$ mikroba pelarut $\mathrm{K}+$ mikroba pemfiksasi $\mathrm{N}]$ lebih tinggi dibandingkan dengan kontrol pada semua varietas yang diuji.

Tabel 2. Pengaruh perlakuan terhadap kadar hara tanaman dan beberapa karakteristik kimia tanah

\begin{tabular}{|c|c|c|c|c|c|c|}
\hline Perlakuan & $\mathrm{N}$ & $\mathrm{P}$ & $\mathrm{K}$ & $\mathrm{pH} \mathrm{H}_{2} \mathrm{O}$ & $\mathrm{pH} \mathrm{KCl}$ & C-organik \\
\hline & $(\%)$ & $(\%)$ & $(\%)$ & & & $(\%)$ \\
\hline $\mathrm{V}_{1} \mathrm{P}_{1}$ & $0,57 \mathrm{a}$ & 0,54 & $1,11 \mathrm{a}$ & 5,1 & 4,83 & 2,24 \\
\hline $\mathrm{V}_{1} \mathrm{P}_{2}$ & $0,54 \mathrm{a}$ & 0,35 & $0,84 \mathrm{~b}$ & 5,12 & 4,75 & 2,11 \\
\hline $\mathrm{V}_{1} \mathrm{P}_{3}$ & $0,44 \mathrm{~b}$ & 0,38 & $0,77 \mathrm{bc}$ & 5,15 & 4,66 & 2,39 \\
\hline $\mathrm{V}_{1} \mathrm{P}_{4}$ & $0,43 \mathrm{~b}$ & 0,34 & $0,84 \mathrm{~b}$ & 5,21 & 4,89 & 2,56 \\
\hline $\mathrm{V}_{2} \mathrm{P}_{1}$ & $0,50 \mathrm{ab}$ & 0,36 & $1,09 \mathrm{a}$ & 5,39 & 4,91 & 2,55 \\
\hline $\mathrm{V}_{2} \mathrm{P}_{2}$ & $0,46 \mathrm{~b}$ & 0,45 & $1,05 \mathrm{a}$ & 5,1 & 4,79 & 2,55 \\
\hline $\mathrm{V}_{2} \mathrm{P}_{3}$ & $0,45 \mathrm{~b}$ & 0,38 & $0,77 \mathrm{bc}$ & 4,8 & 4,67 & 2,13 \\
\hline $\mathrm{V}_{2} \mathrm{P}_{4}$ & $0,42 \mathrm{~b}$ & 0,29 & $0,63 \mathrm{c}$ & 4,93 & 4,3 & 2,48 \\
\hline $\mathrm{V}_{3} \mathrm{P}_{1}$ & $0,59 \mathrm{a}$ & 0,33 & $1,05 \mathrm{a}$ & 4,9 & 4,53 & 2,49 \\
\hline $\mathrm{V}_{3} \mathrm{P}_{2}$ & $0,54 \mathrm{a}$ & 0,37 & $0,49 \mathrm{c}$ & 5,04 & 4,8 & 2,51 \\
\hline $\mathrm{V}_{3} \mathrm{P}_{3}$ & $0,28 \mathrm{c}$ & 0,39 & $0,56 \mathrm{c}$ & 4,94 & 4,75 & 2,68 \\
\hline $\mathrm{V}_{3} \mathrm{P}_{4}$ & $0,26 \mathrm{c}$ & 0,38 & $0,49 \mathrm{c}$ & 4,8 & 4,72 & 2,51 \\
\hline Anava & & & & & & \\
\hline Kombinasi & $*$ & ns & $*$ & ns & ns & ns \\
\hline Varietas & ns & ns & $*$ & ns & ns & ns \\
\hline Pupuk & $*$ & ns & $*$ & ns & ns & ns \\
\hline Ket : angka-angka yang diikuti oleh hurufyang sama pada kolom \\
yang sama berbeda tidak nyata pada DMRT $5 \%$ & \\
\hline
\end{tabular}

Keberadaan mikroba tanah menjadi salah satu faktor yang mempengaruhi pertumbuhan tanaman berupa perbaikan kualitas kesuburan tanah. Hasil penelitian menunjukkan bahwa perlakuan $\mathrm{P}_{1}$ [inokulan ganda mikroba pelarut $\mathrm{p}(\mathrm{pf})+$ mikroba pelarut $\mathrm{K}+$ mikroba pemfiksasi $\mathrm{N}$ ] yang dikombinasikan dengan varietas Inpago 10 menghasilkan tinggi tanaman tertinggi yaitu $106,32 \mathrm{~cm}$, sedangkan jumlah anakan produktif dihasilkan oleh $\mathrm{P}_{1}$ [inokulan ganda mikroba pelarut $\mathrm{p}$ (pf) + mikroba pelarut $\mathrm{K}+$ mikroba pemfiksasi $\mathrm{N}$ ] yang dikombinasikan dengan varietas Serantan yaitu 26,5 anakan (Tabel 3). Hal tersebut kaitannya dengan 
kemampuan mikroba dalam membantu tanaman menyerap unsur hara terutama $\mathrm{N}, \mathrm{P}$, dan $\mathrm{K}$ sehingga pertumbuhan tanaman meningkat.

Tabel 3. Pengaruh perlakuan terhadap pertumbuhan tanaman

\begin{tabular}{|c|c|c|c|c|}
\hline \multirow{2}{*}{ Perlakuan } & \multirow{2}{*}{$\begin{array}{c}\text { Tinggi } \\
\text { Tanaman } \\
(\mathrm{cm})\end{array}$} & \multirow{2}{*}{$\begin{array}{c}\text { Jumlah } \\
\text { Anakan } \\
\text { Total } \\
\end{array}$} & \multicolumn{2}{|c|}{ Bobot Kering (g) } \\
\hline & & & Batang & Akar \\
\hline $\mathrm{V}_{1} \mathrm{P}_{1}$ & $106,32 \mathrm{a}$ & $17,5 \mathrm{~b}$ & 54,8 & 34,6 \\
\hline $\mathrm{V}_{1} \mathrm{P}_{2}$ & $100,33 \mathrm{a}$ & $11,5 \mathrm{~d}$ & 42,3 & 30,2 \\
\hline $\mathrm{V}_{1} \mathrm{P}_{3}$ & $100,30 \mathrm{a}$ & $16,5 \mathrm{~b}$ & 34,9 & 17,8 \\
\hline $\mathrm{V}_{1} \mathrm{P}_{4}$ & $102,31 \mathrm{a}$ & $12,0 \mathrm{~cd}$ & 26,2 & 18,2 \\
\hline $\mathrm{V}_{2} \mathrm{P}_{1}$ & $55,17 \mathrm{bc}$ & $26,5 \mathrm{a}$ & 30,6 & 16,8 \\
\hline $\mathrm{V}_{2} \mathrm{P}_{2}$ & $56,17 \mathrm{bc}$ & $23,5 \mathrm{ab}$ & 30,2 & 19,4 \\
\hline $\mathrm{V}_{2} \mathrm{P}_{3}$ & $48,14 \mathrm{c}$ & $27,5 \mathrm{a}$ & 34,9 & 28,1 \\
\hline $\mathrm{V}_{2} \mathrm{P}_{4}$ & $68,20 \mathrm{~b}$ & $24,0 \mathrm{a}$ & 27 & 17,4 \\
\hline $\mathrm{V}_{3} \mathrm{P}_{1}$ & $49,10 \mathrm{c}$ & $17,5 \mathrm{~b}$ & 32,5 & 22,9 \\
\hline $\mathrm{V}_{3} \mathrm{P}_{2}$ & $68,20 \mathrm{~b}$ & $18,0 \mathrm{~b}$ & 36,3 & 24,6 \\
\hline $\mathrm{V}_{3} \mathrm{P}_{3}$ & $60,18 \mathrm{~b}$ & $19,5 \mathrm{~b}$ & 16,3 & 9,6 \\
\hline $\mathrm{V}_{3} \mathrm{P}_{4}$ & $68,20 \mathrm{~b}$ & $13,0 \mathrm{~cd}$ & 35 & 19,3 \\
\hline \multicolumn{5}{|l|}{ Anava } \\
\hline Kombinasi & $*$ & $*$ & ns & ns \\
\hline Varietas & $*$ & ns & $*$ & $*$ \\
\hline Pupuk & $*$ & $*$ & $*$ & ns \\
\hline $\begin{array}{l}\text { Ket : angka- } \\
\text { pada kolom } \\
\text { DMRT } 5 \%\end{array}$ & 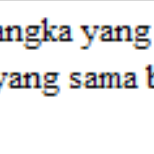 & . & . & $\begin{array}{l}\text { sama } \\
\text { da }\end{array}$ \\
\hline
\end{tabular}

\section{KESIMPULAN}

Berdasarkan hasil penelitian dapat disimpulkan bahwa kawasan pesisir memiliki potensi untuk pengembangan budidaya padi gogo. Secara umum hasil penelitian menunjukkan bahwa inokulan ganda pupuk hayati yang digunakan mampu meningkatkan serapan hara tanaman, karakteristik biologi tanah dan pertumbuhan pagi gogo dibandingkan dengan kontrol. Secara spesifik perlakuan terbaik dihasilkan oleh aplikasi inokulan ganda mikroba pelarut $\mathrm{p}(\mathrm{pf})+$ mikroba pelarut $\mathrm{K}+$ mikroba pemfiksasi $\mathrm{N}$ yang dikombinasikan dengan padi gogo varietas Inpago 10.

\section{DAFTAR PUSTAKA}

Abdurachman A, Dariah, A., Mulyani, A. (2008). Strategi dan teknologi pengelolaan lahan kering mendukung pengadaan pangan nasional. $J$ Litbang Pert., 27(2), 43-49

Ashraf, M \& Harris, P.J.C. (2004). Potential biochemical indicators of salinity tolerance in plants. Plant Science, 166(1), 3-16.
Astuti.Y.W, Widodo, L.U. \& Budisantosa, I. (2013). Pengaruh bakteri pelarut fosfat dan bakteri penambat nitrogen terhadap pertumbuhan tanaman tomat pada tanah masam. Biosfera $A$ Scientific Journal. 30(3), 134-142.

Aquilanti, L, Favilli, F., Clementi, F. (2004). Comparison of different strategies for isolation and preliminary identification of Azotobacter from soil samples. Soil Biol. Biochem. 36(9), 1475-1483.

Bais, H.P., Weir, T.L., Perry, L.G., Gilroy, S. \& Vivanco, J.M. (2006). The Role of root exudates in Rhizosphere interactions with plants and other organisms. Annu Rev Plant Biol., 57, 233-266.

Basak, B.B. \& Biswas, D.R. (2005). Influence of potassium solubilizing microorganism (Bacillus mucilaginosus) and waste mica on potassium uptake dynamics by Sudan grass (Sorghum vulgare Pers.) grown under two Alfisols. Plant Soil, 3(17), 235-255.

Bertham.Y.H. 2002. Respon tanaman kedelai (Glycine $\max (\mathrm{L})$ Merill ) terhadap pemupukan fosfor dan kompos jerami pada tanah Ultisol. $J$ Ilmu-Ilmu Pertanian Indonesia, 4(2), 78-83.

Bertham Y.H., Handajaningsih, M. \& Ganefianti, D.W. (2013). Uji Coba Budidaya Cabai Organik di Lahan Pesisir Bengkulu. Prosiding Semirata Bidang Ilmu-Ilmu Pertanian Fakultas Pertanian UNTAN dan BKS PTN Wilayah Barat,12,99106.

Bertham Y.H, Nusantara, A.D., Pujiwati, H. \& Andani, A. (2016-2018). Pemberdayaan Masyarakat Kawasan Pesisir Lautan Berbasis Budidaya Kedelai Hayati dan Organik. Penelitian Hibah Kompetensi 3 tahun. Universitas Bengkulu, Bengkulu.

Bertin, C., Yang, X. \& Weston, L.A. (2003). The Role of root exudates and allelochemicals In the rhizosphere. Plant Soil, 256(1), 67-83.

Budiharsono, S. (2001). Teknik Analisis Pembangunan Wilayah Pesisir dan Lautan. Pradnya Paramita, Jakarta.

Chiu, H., Peters, J.W., Lanzilotta, W.N., Ryle, M.J., Seefeldt, L.C., Howard, J.B. \& Rees, D.S. (2001). MgATP-bound and nucleotide-freestructure of a nitrogenase protein complex between the leu 127 delta-Fe-protein and the MoFe-protein. Biochemistry, 40(3), 641-650.

Don, N, T. \& Diep, N. (2014). Isolation, characterization and identification of phosphate and potassium solubilizing bacteria from weathered materials of granite rock mountain, That Son, an Giang province, Vietnam. Americ $J$ LifeSci., 2(5), 282-291.DOI:https://10.11648/ j.ajls.20140205.16.

Doornbos, R.F., van Loon, L.C. \& Bakker, P.A.H.M. (2012). Impact of root exudates and plant defense 
signaling on bacterial communities in the rhizosphere. A review. Agron. Sustain. Dev., 32, 227-243.

Gorham, J. (2007). Sodium. In Barker, A.V \& Pilbeam, D.J. (eds). Handbook of plant Nutrition. Taylor \& Francis. p. 569-575

Herison, C., Turmudi, E., Handayaningsih, M. \& Dewi, K.H. (2015). Peningkatan adaptibilitas Gembili (Dioscorea esculenta L.) pada lahan pesisir dengan penambahan pupuk amonium sulfat (ZA) dan mulsa organik. Akta Agrosia, 18(2), 39-46. DOI: https://doi.org/10.31186/aa.18.2.40-46.

Hu X., Chen, J. \& Guo, J. (2006). Two phosphate and potassium solubilizing bacteria isolated from Tianmu Mountain, Zhejiang, China. World $J$ Microbiol Biotechnol.. 22(9), 983-990.

Jones, R., Sun, W., Tang, C.S., Robert, F.M. (2004). Phytoremediation of petroleum hydrocarbons in tropical coastal soils. II. Microbial response to plant roots and contaminant. Environ Sci Pollut Research, 11, 340-346.

Kementerian Pertanian Republik Indonesia. (2017). Statistik Pertanian. Jakarta Pusat Data dan Sistem Informasi Pertanian, Kementerian Pertanian Republik Indonesia, Jakarta.

Keneni, A., Assefa, F. \& Prabu, P. C. (2010). Isolation of phosphate solubilizing bacteria from the rhizosphere of Faba Bean of Ethiopia and their abilities on solubilizing insoluble phosphates. J. Agr. Sci. Tech., 12(1), 79- 89.

Nurhidayati. T, K.I Purwani, D. \& Ermavitalini. (2010). Isolasi mikoriza vesikular arbuskular pada lahan kering di Jawa Timur. Berkala Penelitian Hayati. (4), 43-46.

Nurmegawati \& Wibawa, W. (2012). Adaptasi Varietas Unggul Baru pada Lahan Rawa Pasang Surut di Provinsi Bengkulu. Balai Pengkajian Teknologi Pertanian Bengkulu, Bengkulu.

Nusantara, A.D., Bertham, Y.H. \& Murcitro, B.G. (2018). 2018. Uji Tumbuh Edamame Dengan
Memanfaatkan Potensi Pupuk Hayati dalam Meningkatkan Pertumbuhan Produktivitas Edamame di Kawasan Pesisir. Penelitian Unggulan Universitas. Universitas Bengkulu.

Oktaviani, Hasanah \& Barus. (2014). Pertumbuhan kedelai (Glycine max L. Merrill) dengan aplikasi fungi mikoriza arbuskular (FMA) dan konsorsium mikroba. Jurnal Online Agroekoteknologi. 2 (2), 905-918.

Purwaningsih, S. (2003). Isolasi, populasi dan karakterisasi bakteri pelarut fosfat pada tanah dari Taman Nasional Bogani Nani Wartabone, Sulawesi Utara. J. Biologi, 3(1), 22-31.

Simamora, R.M., Yulian \& Turmudi, E. (2018). Penampilan 10 aksesi talas (Colocasio esculenta (L). Schott) di lahan pesisir Bengkulu. J. IlmuIlmu Pertanian Indonesia, 20(1), 19-25. DOI:https://doi.org/10.31186/jipi.20.1.19-25.

Singh G, D., Biswas, R. \& Marwaha, T.S. (2010). Mobilization of potassium from waste mica by plant growth promoting rhizobacteria and its assimilation by maize (Zea mays) and wheat (Triticum aestivum L). J Plant Nutr., 33(8), 1236-1251. DOI: https://doi.org/10.1080/ 01904161003765760.

Sudaryono. (2001). Pengaruh pemberian bahan pengkondisi tanah terhadap sifat fisik dan kimia tanah pada lahan marginal berpasir. Jurnal Teknologi Lingkungan, 2(1), 106-112.

Syam'un, E. Kaimuddin \& Dachlan, A. (2012). Pertumbuhan vegetatif dan serapan tanaman $\mathrm{N}$ yang diaplikasi pupuk $\mathrm{N}$ anorganik dan mikroba penambat N non-simbiotik. J. Agrivigor, 11 (2), 251-261.

Zuhry, E. \& Puspita, F. (2008). Pemberian cendawan mikoriza arbuskular (CMA) pada tanah podsolik merah kuning terhadap pertumbuhan dan produksi kedelai (Glycine max (L) Merill. J. Sagu, 7(2), 25-29. 